\title{
Knowledge on biodiversity in focus
}

\author{
Torkild Bakken and Thrine Moen Heggberget
}

Bakken T and Heggberget TM. 2008. Knowledge on biodiversity in focus. Fauna norvegica 26/27: 1-2.

Torkild Bakken, Museum of Natural History and Archaeology, Norwegian University of Science and Technology, NO-7491 Trondheim, Norway

E-mail: torkild.bakken@vm.ntnu.no

Thrine Moen Heggberget, Norwegian Institute for Nature Research, Tungasletta 2, NO-7485

Trondheim, Norway

\begin{abstract}
After some delay we are happy to continue the publication of Fauna norvegica. A new editor and editorial office has been assigned since the last edition. At the same time, there has also been a change in the editorial policy, to increase the focus on diversity, abundance and faunal changes. We will also focus on taxonomy and systematics, which is often coupled to studies in diversity and biogeography. A closer inspection of our new "Instructions to authors" will reveal that topics covering ecology and ethology have been left out. There are already a number of journals that cover these topics, and we want to emphasise the scope here by considering knowledge on biodiversity. Another change we have made is regarding the main geographic focus area, and we now encourage a wider focus towards the Nordic area. This is not a strict limitation as research dealing with other geographical regions may also be accepted.
\end{abstract}

\section{Knowledge on biodiversity - in great need}

The change in editorial policy has been done to emphasise the editorial philosophy that Fauna norvegica has had for several years. We strongly believe that there is a need for a journal that makes sound, faunistic information known and thus accessible to the scientific society and to nature management. Such data much too frequently remain in each scientists files, or become part of voluminous reports with very limited distribution, e.g. because they are written in a national language. Such detailed information is outside the scope of most international journals covering biological science, which are mainly devoted to the development and testing of theories and principles, and to understand the causality. However important that is, natural science and its application in nature management depend on empirical, descriptive data. Presenting such data is the specific niche of Fauna norvegica, thereby providing data for a wider application in both science and management. It will also facilitate the search for co-workers and make available adequate empirical information for more generalized analyses. Conflicting interests in land and water use, and increasingly also in the use of coastal sea areas, pose new challenges in relation to sustained use and conservation of biodiversity, and there is a constant shortage of relevant information on the spatial distribution of organisms.

The important aspects are strongly emphasised in recent initiatives evaluating knowledge of biodiversity in Scandinavia (e.g. Gärdenfors et al. 2005; Kålås et al. 2006). These works represent the recent Swedish and Norwegian red lists, respectively. Attempting to include all available information related to the organism groups that were evaluated, both studies demonstrated inadequacies in the knowledge of distribution, abundance and temporal changes for a significant number of species. In other cases, organisms representing large systematic groups are poorly known or hardly known at all, even in large geographical areas. This has been demonstrated especially in the vast areas represented by the Nordic marine areas (Schander \& Willassen 2005). Also, in earlier work dealing with management and a recently established proposal for marine protected areas in Norway, the range of diversity along the Norwegian coast was described as only superficially known (Sætre 2007). 
These few examples demonstrate the importance of adequate knowledge, and this becomes even clearer when studying the details from particular organism groups (Schander \& Willassen 2005). Alien species pose a great challenge. In order to assess the dispersal of alien genotypes or species into a local ecosystem, basic knowledge about the local fauna is paramount. To detect and follow newly arrived species it is necessary to have broad knowledge on naturally occurring species in the area studied. To find out whether species enter local ecosystems by natural dispersal or via vectors, it is imperative to know about their arrival. Evaluation of the impact an alien species may have will be difficult, if not impossible, without basic knowledge on local diversity (Gederaas et al. 2007).

As new management regimes are set to effect in marine areas, more knowledge of the marine biodiversity is needed. Marine areas may undergo considerable changes due to climatic influence, greater pressure on the coastal zone and increased pollution (Sætre 2007). More studies will be needed to present accurate knowledge in species distribution and abundance, and we will encourage authors to publish their data in order to meet these goals.

\section{Open Access}

Starting from this volume, Fauna norvegica is an open access journal. We believe that research results should be easily accessible to all, and we hope that authors are encouraged to submit their manuscripts to an open access journal.

We also hope that open access is a way to share knowledge in our main focus areas, as specified in our editorial policy: Fauna norvegica focuses mainly on Nordic fauna. In addition to faunistic studies, contributions concerning systematics and taxonomy, biogeography, biodiversity in order to describe abundance and distribution, as well as methodological development, are welcomed and will be considered for publication after peer review.

The former editor wish to thank the scientific and financial contributors for their cooperation to issues published during 12 years. The new editor looks forward to an interesting period of editorial work, and hopes to see that scientists are encouraged to submit their manuscripts, especially in order to contribute to better knowledge and understanding of biodiversity in Nordic areas.

\section{REFERENCES}

Gederaas L, Salvesen I, Viken $\AA$ (eds). 2007. Økologiske risikovurderinger av fremmede arter. 2007 Norwegian Black List - Ecological Risk Analysis of Alien Species. Trondheim. Artsdatabanken. $152 \mathrm{p}$.

Gärdenfors U (ed.). 2005. Rödlistade arter i Sverige 2005. The 2005 Red List of Swedish Species. Uppsala. ArtDatabanken, SLU. 496 p.

Kålås JA, Viken Å, Bakken T (eds). 2006. Norsk rødliste 2006 2006 Norwegian red list. Trondheim. Artsdatabanken. 416 p.

Schander C, Willassen E. 2005. What can biological barcoding do for marine biology? Marine Biology Research 1(1): 79 - 83.

Sætre R (ed.). 2007. The Norwegian Coastal Current - oceanography and climate. Trondheim. Tapir Academic Press. 159 p. 